\title{
PFKFB3 gene deletion in endothelial cells inhibits intraplaque angiogenesis and lesion formation in a murine model of venous bypass grafting
}

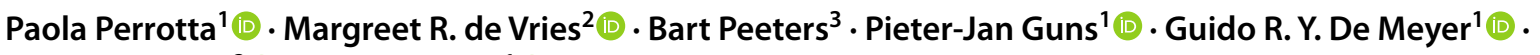 \\ Paul H. A. Quax ${ }^{2}$. Wim Martinet ${ }^{1}{ }^{10}$
}

Received: 9 May 2021 / Accepted: 17 August 2021 / Published online: 25 August 2021

(c) The Author(s) 2021

\begin{abstract}
Vein grafting is a frequently used surgical intervention for cardiac revascularization. However, vein grafts display regions with intraplaque (IP) angiogenesis, which promotes atherogenesis and formation of unstable plaques. Graft neovessels are mainly composed of endothelial cells (ECs) that largely depend on glycolysis for migration and proliferation. In the present study, we aimed to investigate whether loss of the glycolytic flux enzyme phosphofructokinase-2/fructose-2,6-bisphosphatase 3 (PFKFB3) in ECs inhibits IP angiogenesis and as such prevents unstable plaque formation. To this end, apolipoprotein E deficient $\left(\mathrm{ApoE}^{-/-}\right)$mice were backcrossed to a previously generated PFKFB3 ${ }^{\mathrm{f} / \mathrm{fl}} \mathrm{Cdh} 5^{\mathrm{iCre}}$ mouse strain. Animals were injected with either corn oil (ApoE ${ }^{-/-} \mathrm{PFKFB}_{3}{ }^{\mathrm{f} / \mathrm{fl}}$ ) or tamoxifen $\left(\mathrm{ApoE}^{-/-} \mathrm{PFKFB}^{\mathrm{ECKO}}\right.$ ), and were fed a western-type diet for 4 weeks prior to vein grafting. Hereafter, mice received a western diet for an additional 28 days and were then sacrificed for graft assessment. Size and thickness of vein graft lesions decreased by 35 and $32 \%$, respectively, in $\mathrm{ApoE}^{-/-} \mathrm{PFKFB}^{\mathrm{ECKO}}$ mice compared to controls, while stenosis diminished by $23 \%$. Moreover, vein graft lesions in $\mathrm{ApoE}^{-l-} \mathrm{PFKFB} 3^{\mathrm{ECKO}}$ mice showed a significant reduction in macrophage infiltration (29\%), number of neovessels (62\%), and hemorrhages (86\%). ECspecific PFKFB3 deletion did not show obvious adverse effects or changes in general metabolism. Interestingly, RT-PCR showed an increased $\mathrm{M} 2$ macrophage signature in vein grafts from ApoE ${ }^{-/-} \mathrm{PFKFB}^{\mathrm{ECKO}}$ mice. Altogether, EC-specific PFKFB3 gene deletion leads to a significant reduction in lesion size, IP angiogenesis, and hemorrhagic complications in vein grafts. This study demonstrates that inhibition of endothelial glycolysis is a promising therapeutic strategy to slow down plaque progression.
\end{abstract}

Keywords Vein graft · Atherosclerosis · Intraplaque neovascularization · Glycolysis · PFKFB3

\section{Introduction}

Atherosclerosis is a chronic inflammatory disease of the arterial wall and it is one of the most important causes of cardiovascular disease, including severe conditions such as coronary artery disease, myocardial infarction, heart failure,

Wim Martinet

wim.martinet@uantwerpen.be

1 Laboratory of Physiopharmacology, University of Antwerp, Universiteitsplein 1, B-2610 Antwerp, Belgium

2 Department of Surgery, Leiden University Medical Center, Albinusdreef 2, 2333 ZA Leiden, The Netherlands

3 Laboratory Medicine, Antwerp University Hospital, Drie Eikenstraat 655, B-2650 Edegem, Belgium and stroke. Vein bypass grafting is a surgical procedure that uses large saphenous veins to bypass occluded atherosclerotic arteries, thereby allowing revascularization of an ischemic region of the heart or limbs [1]. Unfortunately, at least $40 \%$ of patients suffer from bypass failure within eight years after the procedure due to negative vascular remodeling and intimal hyperplasia [1-4]. Furthermore, vein grafts often present accelerated atherosclerosis with formation of unstable plaques and increased risk of rupture [5-7].

New small vessels can form inside vein grafts to fulfill an increased demand for oxygen and nourishment of the vessel wall. This event, which is further promoted by inflammatory conditions, leads to intraplaque (IP) angiogenesis and contributes to plaque instability in the vein graft $[8,9]$. Indeed, apolipoprotein E deficient $\left(\mathrm{ApoE}^{-/-}\right)$ mice undergoing a vein graft interposition of the carotid 
artery develop unstable plaques with extensive IP neovessels that are often dysfunctional or immature and contribute to lesion destabilization by enhancing leukocyte recruitment and accumulation of cholesterol and platelets $[10,11]$.

Angiogenesis is an energy-intensive process that requires extensive metabolic functioning of endothelial cells (ECs) to support sprouting, migration, and proliferation [12]. Recent studies have shown that ECs in neovessels generate more than $85 \%$ of their ATP by glycolysis $[13,14]$. One of the rate-limiting checkpoints of glycolytic flux is the conversion of fructose-6-phosphate to fructose-1,6-bisphosphate by 6-phosphofructo-1-kinase. Phosphofructokinase-2/fructose-2,6-bisphosphatase (PFKFB) enzymes synthesize fructose-2,6-bisphosphate, an allosteric activator of 6-phosphofructo-1-kinase and the most potent stimulator of glycolysis. Of all PFKFB isoenzymes, PFKFB3 appears the major producer of intracellular fructose-2,6-bisphosphate in ECs. PFKFB3 is upregulated in ECs under inflammatory conditions and its pharmacological inhibition or gene silencing reduces pathological angiogenesis in response to injury and inflammation [15-17]. Previous findings have shown that inhibition of PFKFB3 leads to reduced EC migration and proliferation in vitro. Additionally, sprout number and length of EC spheroids significantly decrease after knocking out PFKFB3 [18].

We have recently reported that the partial glycolysis inhibitor 3PO [3-(3-pyridinyl)-1-(4-pyridinyl)-2-propen1-one] reduces IP angiogenesis and plaque formation [19]. However, the specific role of endothelial PFKFB3 in the context of IP neovascularization and lesion progression remains to be investigated. Therefore, in the present study we used a vein graft procedure in EC-specific conditional PFKFB3 knockout mice on an $\mathrm{ApoE}^{-/-}$background to test whether endothelial PFKFB3 is an important driver of IP angiogenesis and atherosclerotic lesion progression.

\section{Materials and methods}

\section{Animals}

EC-specific conditional PFKFB3 knockout mice $\left(\mathrm{PFKFB} 3^{\mathrm{f} / \mathrm{f}}\right.$ ) were generated by crossbreeding PFKFB $3^{\mathrm{f} /}$ ${ }^{\mathrm{fl}}$ mice with VE-cadherin (PAC)-Cre ${ }^{\mathrm{ERT} 2}$ mice $\left(\mathrm{Cdh} 5^{\mathrm{iCre}}\right)$ [18]. Resulting mice were crossbred with $\mathrm{ApoE}^{-/-}$mice to generate an $\mathrm{ApoE}{ }^{-/}-\mathrm{PFKFB}_{3}{ }^{\mathrm{f} / \mathrm{fl}} \mathrm{Cdh} 5^{\mathrm{iCre}}$ strain. All mice were on a C57BL/6 N background. ApoE ${ }^{-/} \mathrm{PFKFB}^{\mathrm{f} / \mathrm{fl}} \mathrm{C}$ $\mathrm{dh} 5^{\mathrm{iCre}}$ mice (male, 6 weeks old) were injected with tamoxifen $(0.1 \mathrm{~g} / \mathrm{kg}$ body weight) for 5 consecutive days to induce PFKFB3 deletion in ECs, termed $\mathrm{ApoE}^{-/} \mathrm{PFKFB}^{\mathrm{ECKO}}$. ApoE ${ }^{-/} \mathrm{PFKFB} 3^{\mathrm{fl} / \mathrm{fl}} \mathrm{Cdh} 5^{\mathrm{i} C r e}$ control mice, further referred to as $\mathrm{ApoE} \mathrm{E}^{-/-} \mathrm{PFKFB}^{\mathrm{f} / / \mathrm{f}}$ mice, were injected with corn oil using the same protocol. All animal procedures were conducted according to the guidelines from Directive 2010/63/ EU of the European Parliament on the protection of animals used for scientific purposes. Experiments were approved by the ethics committee of the University of Antwerp (reference number 2017-96).

\section{Vein graft surgery}

$\mathrm{ApoE}^{-/-} \mathrm{PFKFB}^{\mathrm{ECKO}}$ and $\mathrm{ApoE} \mathrm{E}^{-/-} \mathrm{PFKFB}^{\mathrm{f} / / \mathrm{fl}}$ mice were fed a western-type diet (Altromin, C1000 diet supplemented with $20 \%$ milkfat and $0.15 \%$ cholesterol, \#100,171) for 4 weeks (Fig. 1). Next, vein graft surgery was performed as described $[5,7,9]$. Briefly, thoracal caval veins from donor $\mathrm{ApoE}^{-/-} \mathrm{PFKFB}^{\mathrm{ECKO}}$ or $\mathrm{ApoE}^{-/-} \mathrm{PFKFB}^{\mathrm{fl} / \mathrm{fl}}$ mice were harvested. In the first group, ApoE ${ }^{-/} \mathrm{PFKFB}^{\mathrm{f} / \mathrm{fl}}$ recipient mice received the caval veins from $\mathrm{ApoE}^{-1-} \mathrm{PFKFB}^{\mathrm{fl} /}$ ${ }^{\mathrm{fl}}$ donor mice; in the second group, $\mathrm{ApoE}^{-1} \mathrm{PFKFB}^{\mathrm{ECKO}}$ mice received the caval veins from $\mathrm{ApoE}^{-1-} \mathrm{PFKFB}_{3}{ }^{\mathrm{ECKO}}$ mice. For each experiment, the right carotid artery of recipient mice was dissected and cut in the middle. On both the

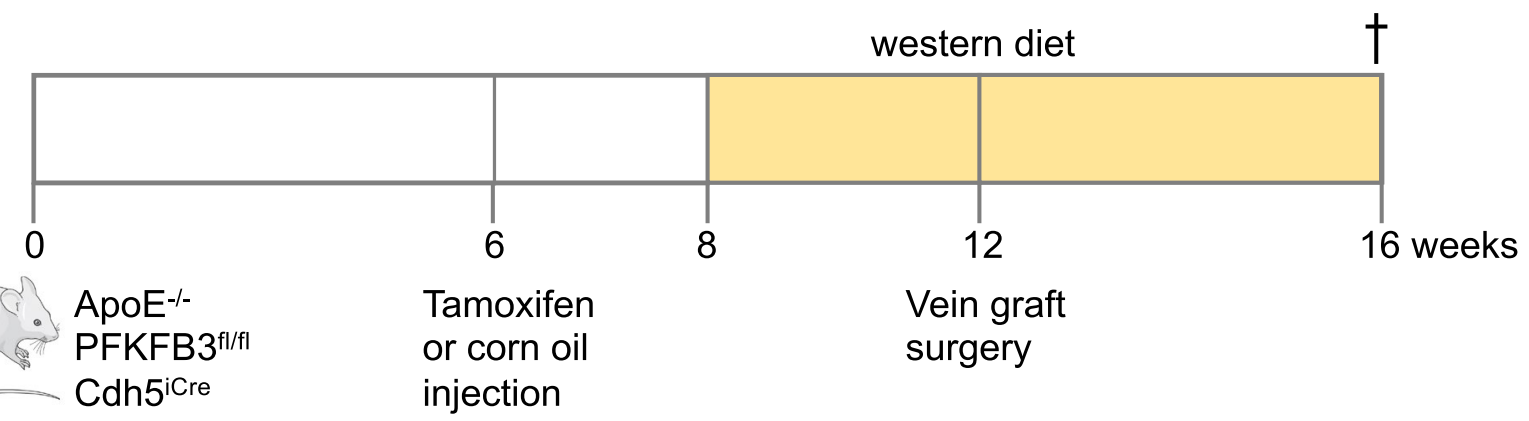

Fig. 1 Schematic overview of the experimental design. ApoE ${ }^{-/}$PFKFB3 $3^{\text {fl/fl }} \mathrm{Cdh} 5^{\text {iCre }}$ mice (6 weeks old) were injected with tamoxifen $(0.1 \mathrm{~g} / \mathrm{kg}$ body weight $)$ for 5 consecutive days to induce PFKFB3 deletion in ECs. Control mice were injected with corn oil using the same protocol. After 2 weeks, mice were fed a western-type diet. Four weeks later, vein graft surgeries were performed. Mice were sacrificed 4 weeks after surgery 
proximal and distal artery end, a nylon cuff was sleeved and fixated with hemostatic clamps. The artery was everted around the cuffs and ligated with 8.0 sutures. Next, the caval veins were positioned over both cuffs, and ligated. Before surgery, mice were anesthetized with midazolam $(5 \mathrm{mg} / \mathrm{kg}$ body weight, i.p., Roche), medetomidine $(0.5 \mathrm{mg} / \mathrm{kg}$ body weight, i.p., Orion) and Fentanyl $(0.05 \mathrm{mg} / \mathrm{kg}$ body weight, i.p., Janssen). After the procedure, mice were antagonized with atipamezole $(2.5 \mathrm{mg} / \mathrm{kg}$ body weight, i.p., Orion) and fluminazenil $(0.5 \mathrm{mg} / \mathrm{kg}$ body weight, i.p., Fresenius Kabi). Buprenorphine $(0.1 \mathrm{mg} / \mathrm{kg}$ body weight, i.p., MSD Animal Health) was given after surgery to relieve pain. Animals were sacrificed under the aforementioned anesthesia 28 days after the graft procedure, followed by $2 \mathrm{~min}$ of in vivo perfusion-fixation.

\section{Histology}

After euthanasia, vein graft segments were collected, fixed in $4 \%$ paraformaldehyde (PFA) for $24 \mathrm{~h}$, dehydrated overnight in $60 \%$ isopropanol, and subsequently embedded in paraffin. Cross sections of vein graft segments were stained with hematoxylin and eosin to evaluate lumen and lesion area, plaque thickness, and percentage of vein stenosis. Neovessels were detected inside vein graft lesions via standard immunohistochemistry using anti-CD31 antibody (endothelial cells; ab124432, Abcam). Anti-TER-119 (550,565, BD Biosciences) was used to determine plaque hemorrhages and anti- $\alpha$-smooth muscle actin ( $\alpha$-SMA) (A2547, SigmaAldrich) was used to determine vascular smooth muscle cell (VSMC) coverage of neovessels. Anti-MAC3 (550,292, Pharmingen), a Masson's Trichrome stain and anti-vascular cell adhesion molecule-1 (VCAM-1) (ab134047, Abcam) were used to stain macrophages, collagen, and VCAM-1 positive ECs, respectively.

\section{Metabolic parameters}

To determine whether $\mathrm{ApoE}^{-/-} \mathrm{PFKFB}^{\mathrm{ECKO}}$ mice exhibit an alteration in glucose metabolism and to characterize the metabolic phenotype, a glucose tolerance test (GTT) and insulin tolerance test (ITT) were done. To perform GTT, mice were fasted for $16 \mathrm{~h}$, injected with a single dose of glucose $(1 \mathrm{~g} / \mathrm{kg}$ body weight, i.p.) and then glucose levels in peripheral blood (from tail) were determined after fixed time intervals (0-30-60-120 min) using a hand-held glucometer (OneTouch Ultra, range 20-600 mg/dL; Lifescan). For ITT, a single insulin dose was injected (Novorapid, 1 $\mathrm{U} / \mathrm{kg}$ body weight, i.p.) in mice and blood glucose levels were monitored as in GTT. Liver enzymes, total cholesterol, and triglycerides were analyzed with an automated Vista 1500 System (Siemens Healthcare Diagnostics). Insulin and $\beta$-hydroxybutyrate in plasma samples were determined with a mouse insulin ELISA kit (80-INSMS-E01, ALPCO) and $\beta$-hydroxybutyrate assay kit (ab83390, Abcam), respectively.

\section{Aortic sprouting}

An aortic ring assay was performed as previously described $[20,21]$. In brief, murine thoracic aortas were dissected, cleaned under sterile conditions, transferred to $10 \mathrm{~cm}$ culture dishes, and cut into $0.5 \mathrm{~mm}$ thick rings with a sterile scalpel. After overnight starvation in serum-free Opti-MEM at $37^{\circ} \mathrm{C}$, ring segments were transferred into wells of a 96-well plate coated with $50 \mu \mathrm{L}$ of a freshly prepared collagen type I solution $(1 \mathrm{mg} / \mathrm{mL})$. The aortic rings remained in Opti-MEM (supplemented with $2.5 \%$ fetal bovine serum and antibiotics) in the presence or absence of vascular endothelial growth factor $(40 \mathrm{ng} / \mathrm{mL}, \mathrm{R} \& D$ Systems). Medium was replaced every 2 days. On day 6 , rings were fixed with $4 \%$ paraformaldehyde and stained with von Willebrand factor antibody (PC054, Binding Site) that was added overnight prior to fluorescence microscopy imaging. The number of sprouts was counted for each ring and sprout numbers per ring were averaged for each group and graphed.

\section{Mouse lung EC isolation}

In order to check the efficiency of PFKFB3 deletion after tamoxifen injection, primary mouse lung ECs were isolated as previously described [22, 23]. Briefly, 4 lungs were harvested, finely minced with scissors, and digested with $1.5 \mathrm{mg} / \mathrm{ml}$ collagenase Type I (Sigma-Aldrich \#C0130) at $37^{\circ} \mathrm{C}$ for $45 \mathrm{~min}$ (under gentle agitation). The digested cell suspension was filtered on a $70 \mu \mathrm{M}$ sterile cell strainer, and spun at $400 \mathrm{~g}$ for $10 \mathrm{~min}$. The pellet was resuspended in 2 $\mathrm{ml}$ of $0.1 \%$ bovine serum albumin and $50 \mu \mathrm{L}$ magnetic dynabeads (ThermoFisher \#11,035) precoated overnight with anti-mouse CD31 (BD Pharmingen \#553,370) for EC-positive selection. After $20 \mathrm{~min}$ at room temperature under slow rotation, the bead-bound cells were recovered with a magnetic separator and washed five times with DMEM containing $10 \%$ fetal bovine serum. Cells were finally resuspended in $10 \mathrm{~mL}$ of complete DMEM medium (DMEM containing $20 \%$ fetal bovine serum, endothelial cell growth supplement, and antibiotics), seeded onto gelatin-precoated $10 \mathrm{~cm}$ plates, and grown for a few days to obtain enough protein material for western blotting.

\section{Western blot analyses}

Cells were lysed in an appropriate volume of Laemmli sample buffer (Bio-Rad) containing $\beta$-mercaptoethanol (SigmaAldrich) and boiled for $5 \mathrm{~min}$. Protein samples were then loaded onto pre-casted Bolt 4-12\% Tris-Bis gels (Invitrogen) and after electrophoresis transferred to Immobilon-FL 
PVDF membranes (Millipore) according to standard procedures. Membranes were blocked for $1 \mathrm{~h}$ with Odyssey blocking buffer (LI-COR Biosciences) diluted 1:5 with PBS. After blocking, membranes were probed overnight at $4{ }^{\circ} \mathrm{C}$ with primary antibodies diluted in Odyssey blocking buffer, followed by $1 \mathrm{~h}$ incubation with IRDye-labeled secondary antibodies at room temperature. Antibody detection was achieved using an Odyssey SA infrared imaging system (LI-COR Biosciences). The intensity of the protein bands was quantified using Image Studio software. The following primary antibodies were used: anti- $\beta$-actin (ab8226, Abcam) and anti-PFKFB3 (ab181861, Abcam). IRDye-labeled secondary antibodies (goat anti-mouse IgG, 926-68070, and goat anti-rabbit IgG, 926-32211) were purchased from LICOR Biosciences.

\section{Real-time RT-PCR}

Total RNA was isolated from formalin-fixed, paraffinembedded tissue sections using an RNeasy FFPE kit (Qiagen) according to the manufacturer's instructions. Reverse transcription was performed with a Sensifast $\mathrm{T}^{\mathrm{TM}}$ cDNA Synthesis Kit (Bioline). Thereafter, Taqman gene expression assays (Applied Biosystems) for CD38 (assay ID: Mm01220906_m1), Gpr18 (assay ID: Mm01224541_ m1), Egr2 (assay ID: Mm00456650_m1), Arg1 (assay ID: Mm00475988_m1), CXCR4 (assay ID: Mm01292123_m1), VEGFA (assay ID: Mm00437306-m1), VCAM-1 (assay ID: Mm01320970_m1), and ICAM-1 (assay ID: Mm00516023_ $\mathrm{m} 1$ ) were performed in duplicate on a QuantStudio 3 realtime PCR system (Applied Biosystems). The parameters for PCR amplification were $95^{\circ} \mathrm{C}$ for 10 min followed by 40 cycles of $95^{\circ} \mathrm{C}$ for $15 \mathrm{~s}$ and $60^{\circ} \mathrm{C}$ for $1 \mathrm{~min}$. Relative expression of mRNA was calculated using the comparative threshold cycle method. All data were normalized for quantity of cDNA input by performing measurements on the endogenous reference gene $\beta$-actin (assay ID: Mm00607939_s1).

\section{Statistics}

All data are expressed as mean \pm SEM. Statistical analyses were performed using GraphPad Prism (version 9) and SPSS (version 25) software. Statistical tests are specified in the figure legends. Differences were considered significant at $P<0.05$.

\section{Results}

\section{ECs of ApoE ${ }^{-/-}$PFKFB3 ${ }^{\mathrm{ECKO}}$ mice are PFKFB3 deficient}

$\mathrm{ApoE}^{-/-} \mathrm{PFKFB} 3^{\mathrm{f} / \mathrm{fl}} \mathrm{Cdh} 5^{\mathrm{iCre}}$ mice were injected with corn oil or tamoxifen to generate $\mathrm{ApoE}{ }^{-/-} \mathrm{PFKFB}^{\mathrm{ff} / \mathrm{fl}}$ control mice and $\mathrm{ApoE}^{-/-} \mathrm{PFKFB}^{\mathrm{ECKO}}$ mice (with PFKFB3 specifically deleted in ECs), respectively (Fig. 1). To assess the efficiency of PFKFB3 deletion after tamoxifen injection, lung ECs from $\mathrm{ApoE}^{-1-} \mathrm{PFKFB}^{\mathrm{f} / / \mathrm{fl}}$ and $\mathrm{ApoE}^{-/-} \mathrm{PFKFB}^{\mathrm{ECKO}}$ mice were isolated and examined by western blotting. PFKFB3 protein levels were reduced by more than $80 \%$ in $\mathrm{ApoE}^{-/-}$PFKFB3 ${ }^{\mathrm{ECKO}}$ mice (Fig. 2A). Similar findings were observed after co-staining of thoracic aorta segments with anti-PFKFB3 and anti-von Willebrand factor antibodies (Fig. 2B).

\section{ECs of ApoE $^{-l-}$ PFKFB3 ${ }^{\text {ECKO }}$ mice show impaired sprouting in an ex vivo mouse aortic ring assay}

Previous findings have shown that inhibition of PFKFB3 leads to a reduction of EC migration and proliferation in vitro [18]. In line with these results, we found that vascular endothelial growth factor-induced sprouting in aortic rings of $\mathrm{ApoE}^{-/} \mathrm{PFKFB}^{\mathrm{ECKO}}$ mice was $65 \%$ less as compared to ApoE ${ }^{-/}$PFKFB $^{\mathrm{fl} / \mathrm{fl}}$ control mice (Supplemental Figure S1). This observation indicates a direct effect of endothelial PFKFB3 on angiogenesis.

\section{PFKFB3 deficiency in ECs does not cause metabolic changes in adult mice}

To evaluate whether EC-specific PFKFB3 gene deletion affects general metabolism, we analyzed plasma samples of $\mathrm{ApoE}^{-/-} \mathrm{PFKFB}^{\mathrm{f} / / \mathrm{fl}}$ and $\mathrm{ApoE} \mathrm{E}^{-/-} \mathrm{PFKFB} 3^{\mathrm{ECKO}}$ mice after 4 weeks of western-type diet. No differences were observed in liver enzymes ( $\gamma$-glutamyltransferase, alanine transaminase, alkaline phosphatase) and insulin (Table 1), indicating that PFKFB3 deletion in ECs has no obvious systemic side effects. Moreover, there were no differences in glucose and insulin tolerance tests after 12 weeks of western-type diet (Supplemental Figure S2), indicating that glucose absorption and insulin receptor sensitivity is normal in both strains. Also, body weight, cholesterol levels, and plasma triglycerides were not statistically different between both groups of mice (Table 1). In addition, levels of the ketone-body $\beta$-hydroxybutyrate were not changed in $\mathrm{ApoE}^{-/} \mathrm{PFKFB} 3^{\mathrm{ECKO}}$ mice as compared to $\mathrm{ApoE}^{-/-} \mathrm{PFKFB} 3^{\mathrm{fl} / \mathrm{fl}}$ mice (Table 1). These observations suggest that endothelial PFKFB3 deletion does not induce a metabolic switch from glucose to fatty acid-derived ketones and does not cause major side effects in $\mathrm{ApoE}^{-/-}$mice.

\section{PFKFB3 deficiency in ECs inhibits neovascularization in vein graft lesions}

Both $\mathrm{ApoE} \mathrm{E}^{-/} \mathrm{PFKFB}^{\mathrm{f} / \mathrm{fl}}$ and $\mathrm{ApoE} \mathrm{E}^{-/-} \mathrm{PFKFB}^{\mathrm{ECKO}}$ mice displayed an intact endothelium 28 days after vein graft surgery (black arrows Fig. 3A, B). Circular-oriented VSMCs were seen 
A

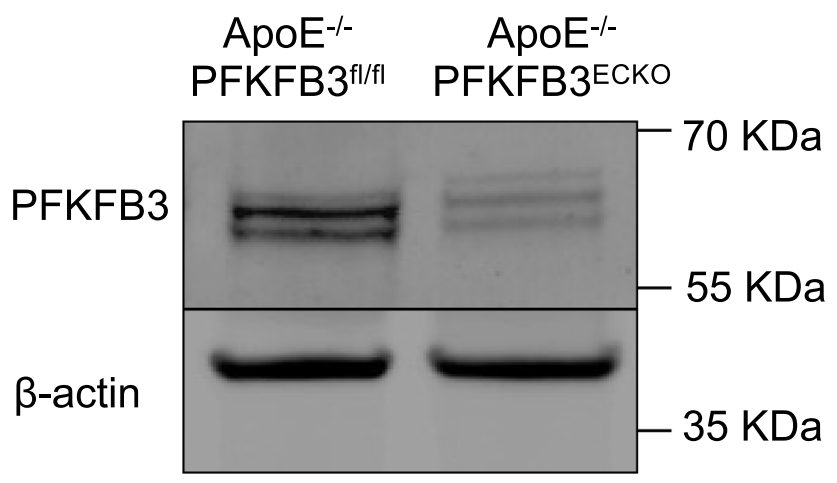

B

\section{Thoracic aorta segments}
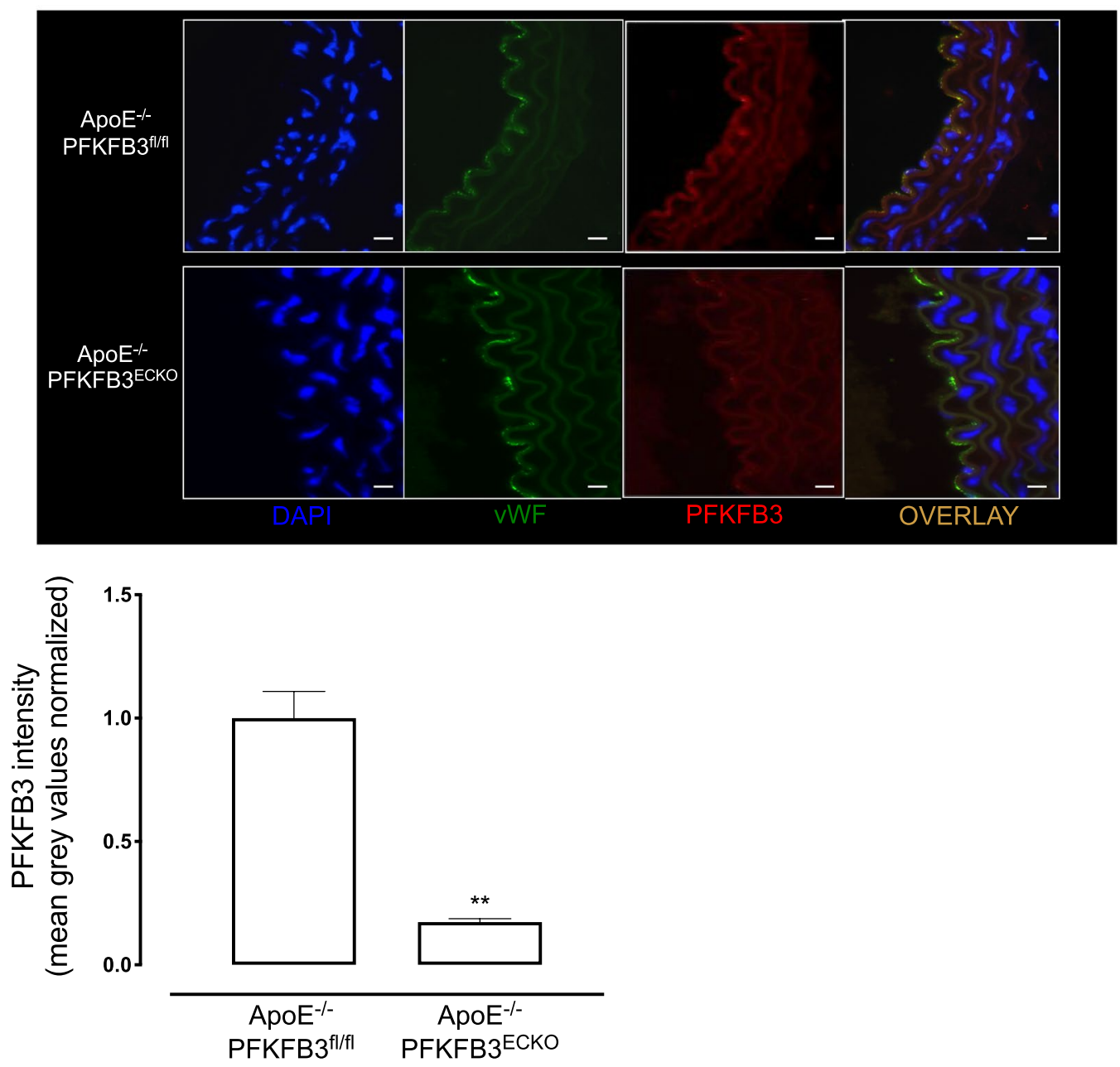

Fig. 2 Validation of PFKFB3 gene deletion in endothelial cells. A Representative western blot showing protein levels of PFKFB3 and $\beta$-actin in primary lung EC. Bars represent relative protein quantification of PFKFB3 normalized to the reference protein $\beta$-actin. $* P<0.05$ versus $\mathrm{ApoE}^{-/-} \mathrm{PFKFB}^{\mathrm{t} / \mathrm{fl}}$ (Independent samples $t$ test; $n=3$ ). B Representative thoracic aorta segments of

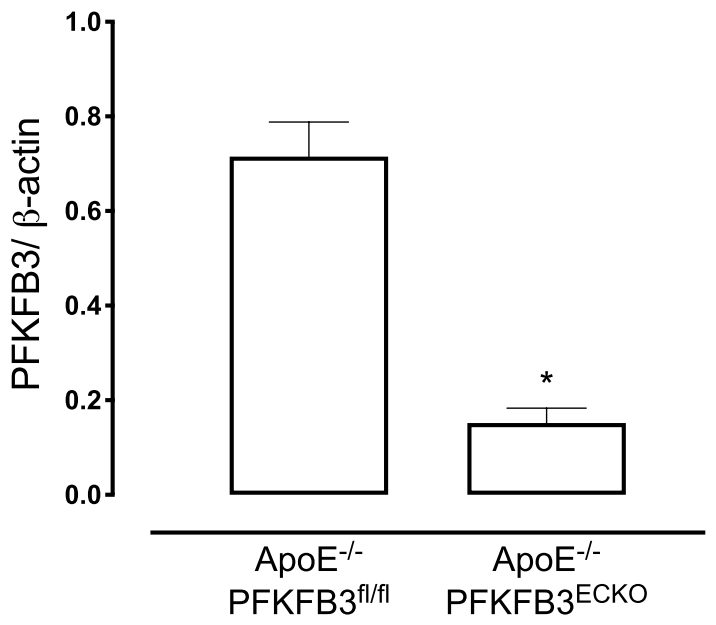


Table. 1 Metabolic parameters of $\mathrm{ApoE}^{-/-} \mathrm{PFKFB} 3^{\mathrm{t} / \mathrm{fl}}$ and $\mathrm{ApoE}^{-/-} \mathrm{PFKFB}^{\mathrm{ECKO}}$ mice

\begin{tabular}{lcc}
\hline Metabolic parameters & ApoE $^{-/-} \mathrm{PFKFB}^{\mathrm{f} / \mathrm{fl}}$ & ApoE $^{-/-} \mathrm{PFKFB}^{\mathrm{ECKO}}$ \\
\hline Liver enzymes & & \\
$\gamma$-Glutamyltransferase (U/L) & $5.5 \pm 0.6$ & $5 \pm 0.4$ \\
Alanine transaminase (U/L) & $39 \pm 11$ & $34 \pm 6$ \\
Alkaline phosphatase (U/L) & $132 \pm 13$ & $154 \pm 13$ \\
Fasting blood glucose (mg/dL) & $116 \pm 4$ & $100 \pm 8$ \\
Non-fasting blood glucose (mg/dL) & $152 \pm 9$ & $138 \pm 10$ \\
Insulin (ng/ml) & $0.2 \pm 0.1$ & $0.2 \pm 0.1$ \\
Total cholesterol (mg/dL) & $306 \pm 2$ & $317 \pm 1$ \\
Body weight $(\mathrm{g})$ & $20 \pm 0.4$ & $19 \pm 0.3$ \\
Triglycerides $(\mathrm{mg} / \mathrm{dL})$ & $79 \pm 23$ & $57 \pm 6$ \\
$\beta$-hydroxybutyrate $(\mu \mathrm{M})$ & $1.9 \pm 0.2$ & $2.0 \pm 0.1$ \\
\hline
\end{tabular}

Data between $\mathrm{ApoE}^{-/-} \mathrm{PFKFB}^{\mathrm{ECKO}}$ and $\mathrm{ApoE}^{-/-} \mathrm{PFKFB}^{\mathrm{f} / / \mathrm{fl}}$ mice are not significantly different. Independent Sample $t$ test, $n=8\left(\mathrm{ApoE}^{-/-} \mathrm{PFKFB}^{\mathrm{f} / / \mathrm{f}}\right)$ or $n=11\left(\mathrm{ApoE}^{-/-} \mathrm{PFKFB}^{\mathrm{ECKO}}\right)$ in $\mathrm{ApoE}^{-/-} \mathrm{PFKFB}^{\mathrm{fl} / \mathrm{fl}}$ and $\mathrm{ApoE^{-/- }} \mathrm{PFKFB}^{\mathrm{ECKO}}$ vein graft lesions, close to the lumen, suggesting a cap-like organization (white arrows, Fig. 3A, B). Foam cells, a small necrotic core, and cholesterol crystals were found particularly in vein grafts of $\mathrm{ApoE}^{-/} \mathrm{PFKFB}^{\mathrm{ft} / \mathrm{fl}}$ mice near the luminal side (asterisks, Fig. 3A, B). Furthermore, neovessels were found through the vein graft wall, predominantly in $A p o E^{-/}$PFKFB $3^{\mathrm{fl} / \mathrm{fl}}$ mice. The newly formed vessels were often leaky as extravasated erythrocytes were found near and outside these microvessels (Fig. 3A, B).

As shown by a CD31 staining, the number of microvessels per lesion was reduced by $62 \%$ in $\mathrm{ApoE}^{-1-} \mathrm{PFKFB} 3^{\mathrm{ECKO}}$ versus $\mathrm{ApoE}^{-1-} \mathrm{PFKFB} 3^{\mathrm{f} / / \mathrm{fl}}$ mice (Fig. 4A, B, E). IP microvessels were further characterized with $\alpha$-SMA staining to detect the presence of a VSMC layer around the microvessels (Fig. 4C, D). VSMC coverage was observed in vein grafts from both $\mathrm{ApoE}^{-/} \mathrm{PFKFB}^{\mathrm{ECKO}}$ and $\mathrm{ApoE}^{-1-} \mathrm{PFKFB}^{\mathrm{E}}{ }^{\mathrm{f} / \mathrm{fl}}$ mice (Fig. 4F). There was no statistical difference between the two groups $(P=0.05)$, although a trend of higher VSMC coverage in $\mathrm{ApoE}^{-/}$PFKFB $3^{\mathrm{ECKO}}$ mice was observed. The organization of the microvessel network was further assessed by immunofluorescence confocal microscopy (Fig. 5). Staining of graft lesions with CD31 antibody revealed IP microvessels that were often covered by VSMCs as demonstrated by $\alpha$-SMA staining (Fig. 5). These findings suggest that IP microvessels are able to reach a significant level of structural and multicellular complexity. Anti-TER-119 staining showed more erythrocyte infiltration into the lesions of $\mathrm{ApoE}^{-/} \mathrm{PFKFB}^{\mathrm{ft} / \mathrm{fl}}$ mice as compared to lesions of $\mathrm{ApoE}^{-/}$PFKFB3 ${ }^{\mathrm{ECKO}}$ mice (Fig. 6A-C), suggesting increased IP vessel leakage in $\mathrm{ApoE}^{-/} \mathrm{PFKFB}^{\mathrm{fl} / \mathrm{fl}}$ mice.

\section{PFKFB3 deficiency in ECs reduces lesion size of vein grafts}

Twenty-eight days after vein graft surgery, the lesion area in the graft was decreased by $36 \%$ in $\mathrm{ApoE}^{-/-} \mathrm{PFKFB}^{\mathrm{ECKO}}$ mice as compared to ApoE ${ }^{-/}$PFKFB $3^{\mathrm{f} / \mathrm{fl}}$ mice (Fig. 7A, B), suggesting a significant role of endothelial PFKFB3 in lesion formation and/or progression. Moreover, vein graft stenosis, lesion thickness, and necrotic area were significantly reduced in vein grafts of $\mathrm{ApoE}^{-1-} \mathrm{PFKFB}^{\mathrm{ECKO}}$ mice (Fig. 7C-E).

\section{PFKFB3 deficiency in ECs decreases macrophage infiltration}

Macrophage accumulation was mainly observed underneath the luminal EC or around the endothelium of microvessels in vein graft lesions of $\mathrm{ApoE}^{-/-} \mathrm{PFKFB}^{\mathrm{ECKO}}$ mice. In vein graft lesions of $\mathrm{ApoE}^{-/} \mathrm{PFKFB}^{\mathrm{f} / \mathrm{fl}}$ mice, macrophages appeared much more diffuse in the vascular wall (Fig. 8A). Quantification of the macrophage infiltration showed a significant decrease in $\mathrm{ApoE}^{-/} \mathrm{PFKFB}_{3}{ }^{\mathrm{ECKO}}$ mice (Fig. 8B). Analysis of vascular cell adhesion molecule-1 (VCAM-1) expression at the luminal side of the vein graft did not reveal significant differences in $\mathrm{ApoE}^{-l-} \mathrm{PFKFB}^{\mathrm{ECKO}}$ mice as compared to $\mathrm{ApoE}^{-/-} \mathrm{PFKFB}^{\mathrm{f} / / \mathrm{fl}}$ mice (Supplemental Figure S3 A-C). 

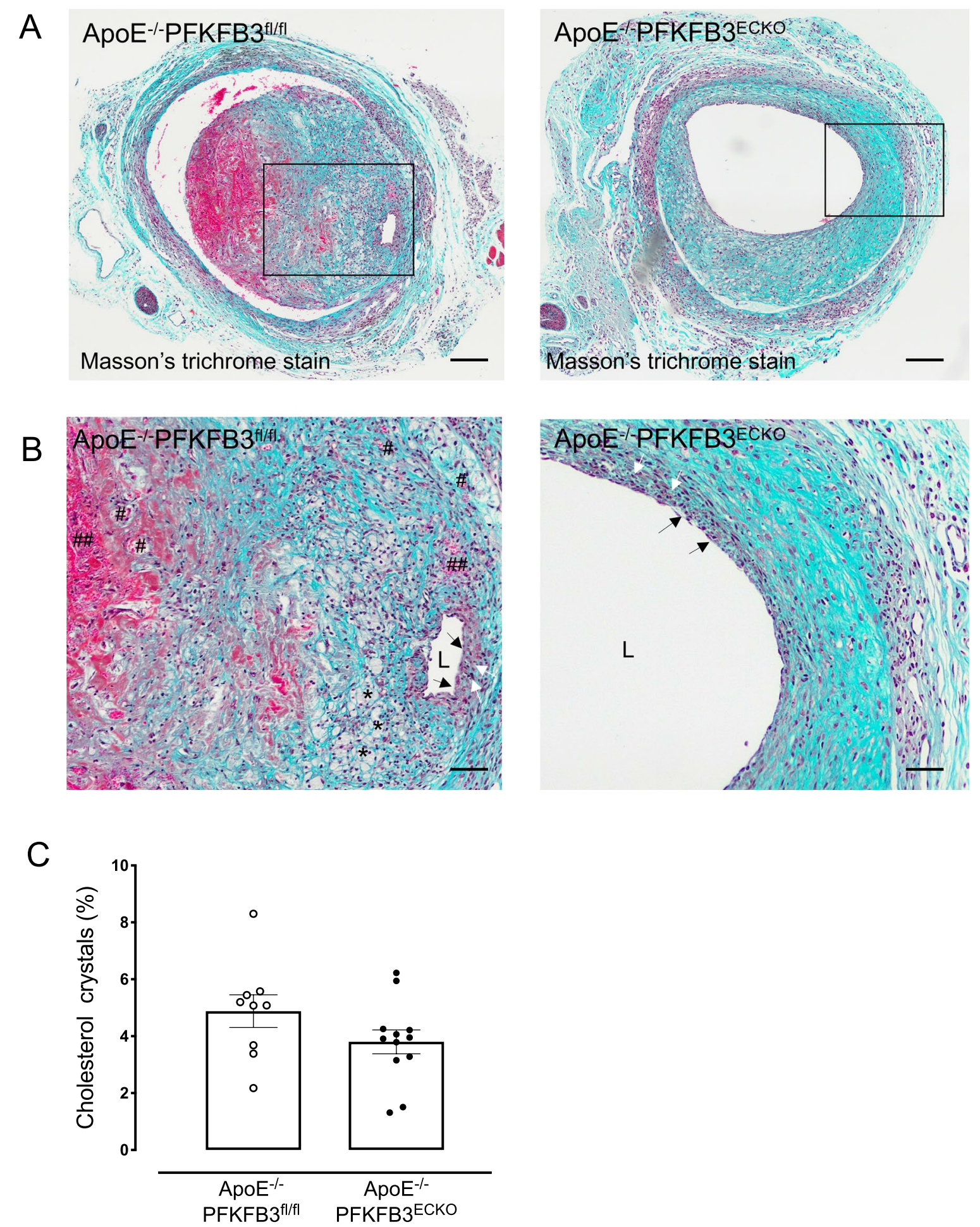

Fig. 3 PFKFB3 deletion in endothelial cells evokes a more stable vein graft lesion phenotype. A Masson's Trichrome staining of representative vein grafts. This staining was used for the evaluation of lesion complexity. Nuclei are stained dark blue, erythrocytes are stained bright-red, and collagen is stained blue. The staining allows easy visualization of intraplaque hemorrhages (red areas) as well as necrotic core and cholesterol crystals (white acellular regions). Scale bar $=200 \mu \mathrm{m}$. B Boxed area of panel A show- ing an almost intact endothelium exposed to the lumen (L) (black arrows), a fibrous cap with numerous vascular smooth muscle cells (white arrows), small foam cells (asterisks), an area with extravasated erythrocytes (\#\#), and neovascularization (\#). Scale bar $=100 \mu \mathrm{m}$. C Quantification of foam cells in vein graft lesions of $\mathrm{ApoE}^{-/-} \mathrm{PFKFB}^{\mathrm{fl} / \mathrm{fl}}$ and $\mathrm{ApoE^{-/ }} \mathrm{PFKFB}^{\mathrm{ECKO}}$ mice. Independent samples $t$ test; $n=9\left(\mathrm{ApoE}^{-/-} \mathrm{PFKFB}^{\mathrm{f} / / \mathrm{f}}\right)$ or $n=12$ $\left(\mathrm{ApoE}^{-/-} \mathrm{PFKFB}^{\mathrm{ECKO}}\right)$ 

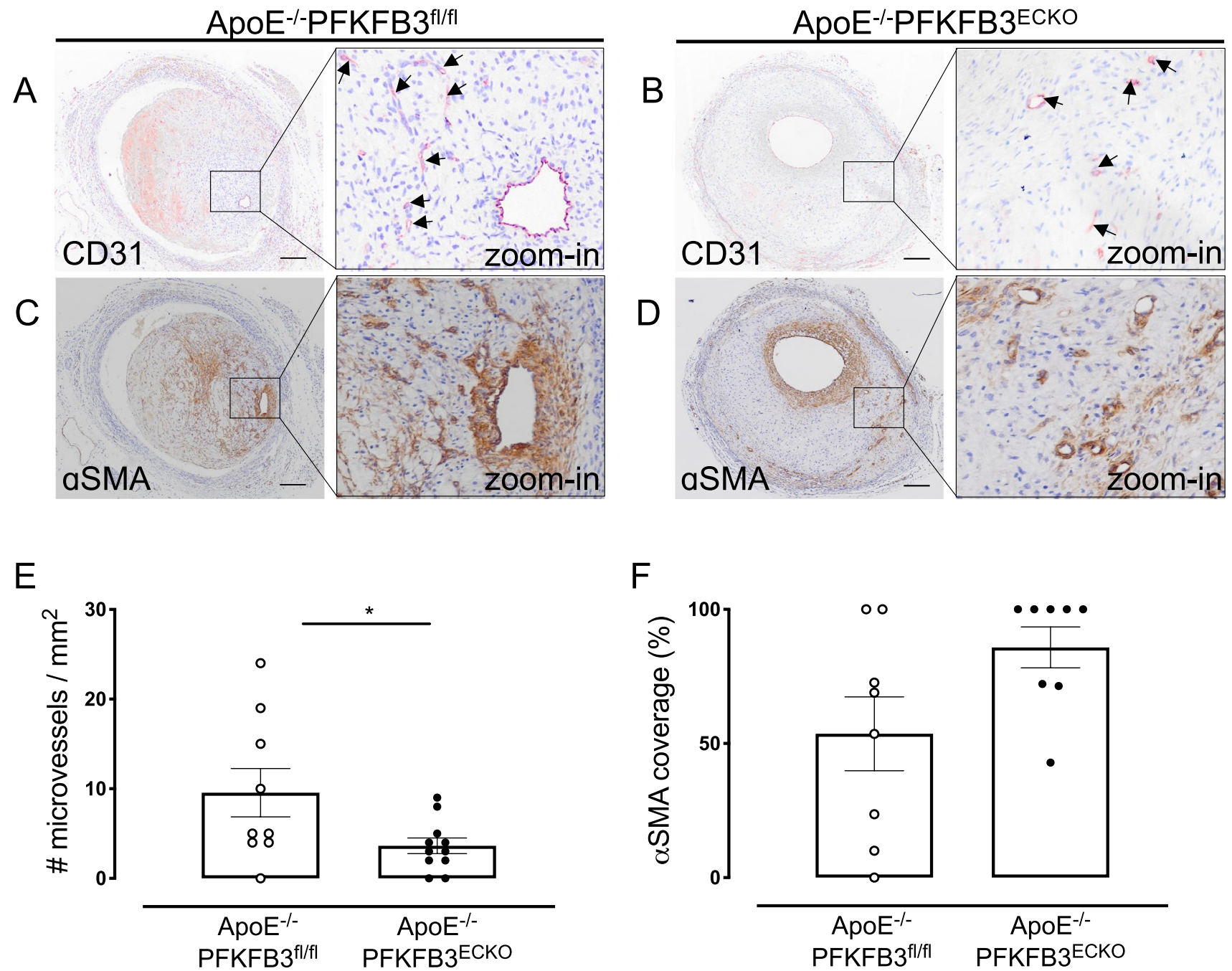

Fig. 4 PFKFB3 deficiency in endothelial cells inhibits intraplaque neovascularization in vein graft lesions but does not alter $\alpha$-SMA coverage of microvessels. A and B Representative vein graft lesions stained with CD31 antibody. Endothelial cells are detected as CD31 positivity (dark violet) around the vessel lumen. Microvessels are marked by arrows. Scale bar $=200 \mu \mathrm{m}$. C and D Representative vein graft lesions stained with anti- $\alpha$-SMA. Vascular smooth muscle cells in the vessel wall are stained by the $\alpha$-SMA antibod-

\section{RT-PCR reveals an elevated $M 2$ macrophage signature in vein grafts of $\mathrm{ApOE}^{-/-}$PFKFB3 ${ }^{\mathrm{ECKO}}$ mice}

To obtain more insight into the mechanisms underlying the observed phenotype in vein grafts of $\mathrm{ApoE}^{-1}$ PFKFB $3^{\mathrm{ECKO}}$ mice, real-time RT-PCR reactions were performed (Fig. 9). Neither the expression of VCAM-1 and intercellular adhesion molecule-1 (ICAM-1) nor the expression of hypoxia markers C-X-C chemokine receptor 4 (CXCR4) and vascular endothelial growth factor A (VEGFA) significantly changed in vein grafts of $\mathrm{ApoE}^{-1-} \mathrm{PFKFB} 3^{\mathrm{ECKO}}$ mice as compared to vein grafts of $\mathrm{ApoE}^{-/-}$PFKFB ${ }^{\mathrm{t} / \mathrm{fl}}$ mice. mRNA levels of M1 macrophage markers CD38 and G-protein coupled

ies (brown). E Quantification of microvessels in vein grafts of $\mathrm{ApoE}^{-/} \mathrm{PFKFB}^{\mathrm{fl} / \mathrm{fl}}$ and $\mathrm{ApoE}^{-/} \mathrm{PFKFB}^{\mathrm{ECKO}}$ mice. $* P=0.035$ versus $\mathrm{ApoE}^{-/-} \mathrm{PFKFB}^{\mathrm{fl} / \mathrm{fl}}$. Independent samples $t$ test; $n=9$ $\left(\mathrm{ApoE}^{-/-} \mathrm{PFKFB}^{\mathrm{fl} / \mathrm{fl}}\right)$ or $n=11\left(\mathrm{ApoE}^{-/-} \mathrm{PFKFB}^{\mathrm{ECKO}}\right)$. F Quantification of $\alpha$-SMA coverage of microvessels in vein grafts of $\mathrm{ApoE}^{-/-} \mathrm{PFKFB}^{\mathrm{fl} / \mathrm{fl}}$ and $\mathrm{ApoE}{ }^{-/-} \mathrm{PFKFB}^{\mathrm{ECKO}}$ mice. Independent samples $t$ test did not show statistical significance $(n=8$ for both groups)

receptor 18 (GPR18) did not change either. However, mRNA expression of the M2 markers Early growth response protein 2 (Egr2) and Arginase-1 (Arg1) were elevated in vein grafts of $\mathrm{ApoE}^{-/}{ }^{-} \mathrm{PFKFB}^{\mathrm{ECKO}}$ mice.

\section{Discussion}

IP angiogenesis is frequently observed inside human vein graft lesions and is recognized as a contributing factor of plaque vulnerability $[3,6,10,11,24]$. In the present study, we crossed EC-specific PFKFB3 knockout mice with $\mathrm{ApoE}^{-1-}$ mice to investigate the role of EC glycolysis 

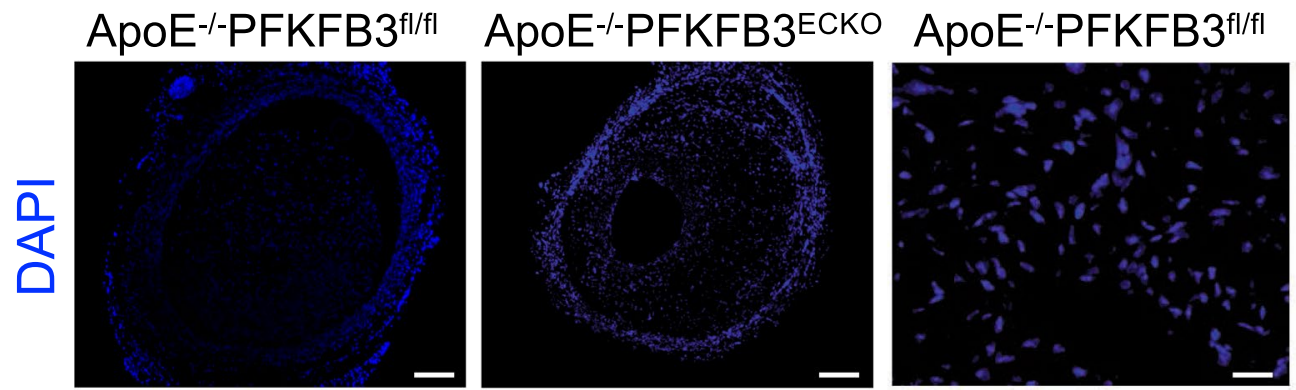

ApoE-/-PFKFB3ECKO
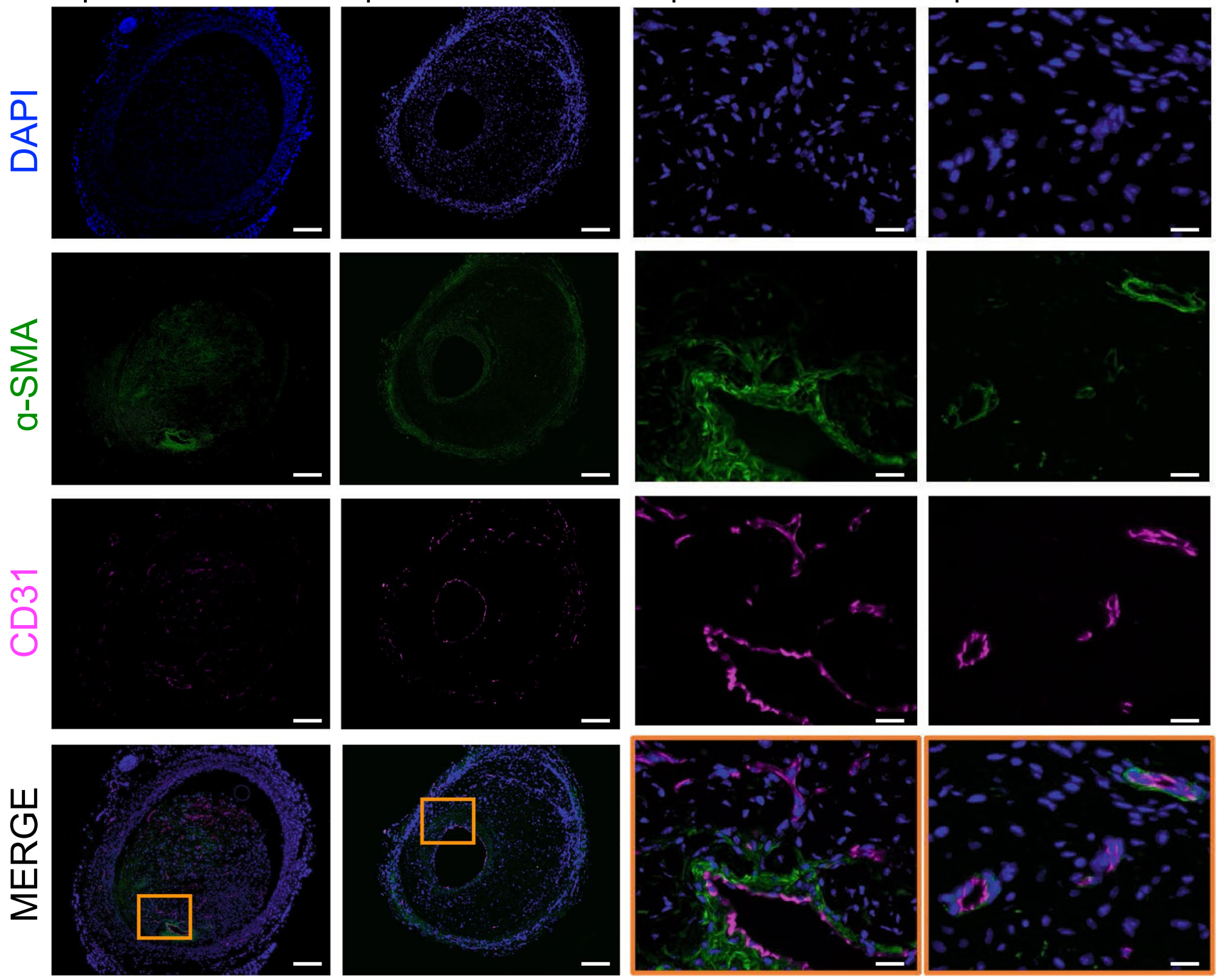

\section{$4 X$}

\section{$20 X$}

Fig. 5 Examples of atherosclerotic lesions in vein grafts of $\mathrm{ApoE}^{-/-} \mathrm{PFKFB}^{\mathrm{f} / / \mathrm{fl}}$ and $\mathrm{ApoE}^{-/-} \mathrm{PFKFB}^{\mathrm{ECKO}}$ mice stained with anti-CD31, $\alpha$-SMA, and DAPI. An overlay of the three stainings is

also shown as well as a magnification (20x) of the boxed areas showing mature and immature vessels. Scale bar $=500 \mu \mathrm{m}(4 \mathrm{x})$ or $100 \mu \mathrm{m}$ (20x)

modulation in vein graft IP angiogenesis. To our knowledge, this is the first study using a conditional EC-specific PFKFB3 knockout mouse in the context of advanced atherosclerosis.

First of all, we did not observe any adverse effects or changes in general metabolism after PFKFB3 deletion in ECs. Circulating liver enzymes, blood glucose, insulin, and total cholesterol were not affected. Also glucose and insulin tolerance tests were similar in $\mathrm{ApoE}^{-/}-\mathrm{PFKFB} 3^{\mathrm{Al} / \mathrm{fl}}$ versus $\mathrm{ApoE}^{-1-} \mathrm{PFKFB} 3^{\mathrm{ECKO}}$ mice. Ketone-body $\beta$-hydroxybutyrate was not changed in both groups. These findings suggest that PFKFB3 deletion in ECs does not lead to severe side effects or to a major metabolic switch in $\mathrm{ApoE}^{-/-}$mice. In line with these findings, recent evidence indicates that the immune cell distribution in peripheral blood and lymphoid organs is unaffected after systemic treatment of mice with PFKFB3 inhibitor PFK158 [25].

Next, and in line with previous studies, we found that PFKFB3 deletion impaired vessel sprouting from aortic rings. Along these lines, $\mathrm{ApoE^{-/ }}{ }^{-} \mathrm{PFKFB} 3^{\mathrm{ECKO}}$ mice showed a significantly reduced number of microvessels in vein graft lesions, albeit without a clear impact on hypoxia markers such as CXCR4 and VEGFA. Moreover, IP microvessels in $\mathrm{ApoE}^{-/}{ }^{-} \mathrm{PFKFB} 3{ }^{\mathrm{ECKO}}$ showed a trend toward higher VSMC 
A

ApoE ${ }^{-/-P F K F B 3} 3^{\text {fl/fl }}$

TER119

\section{ApoE--PFKFB3ECKO}

TER119
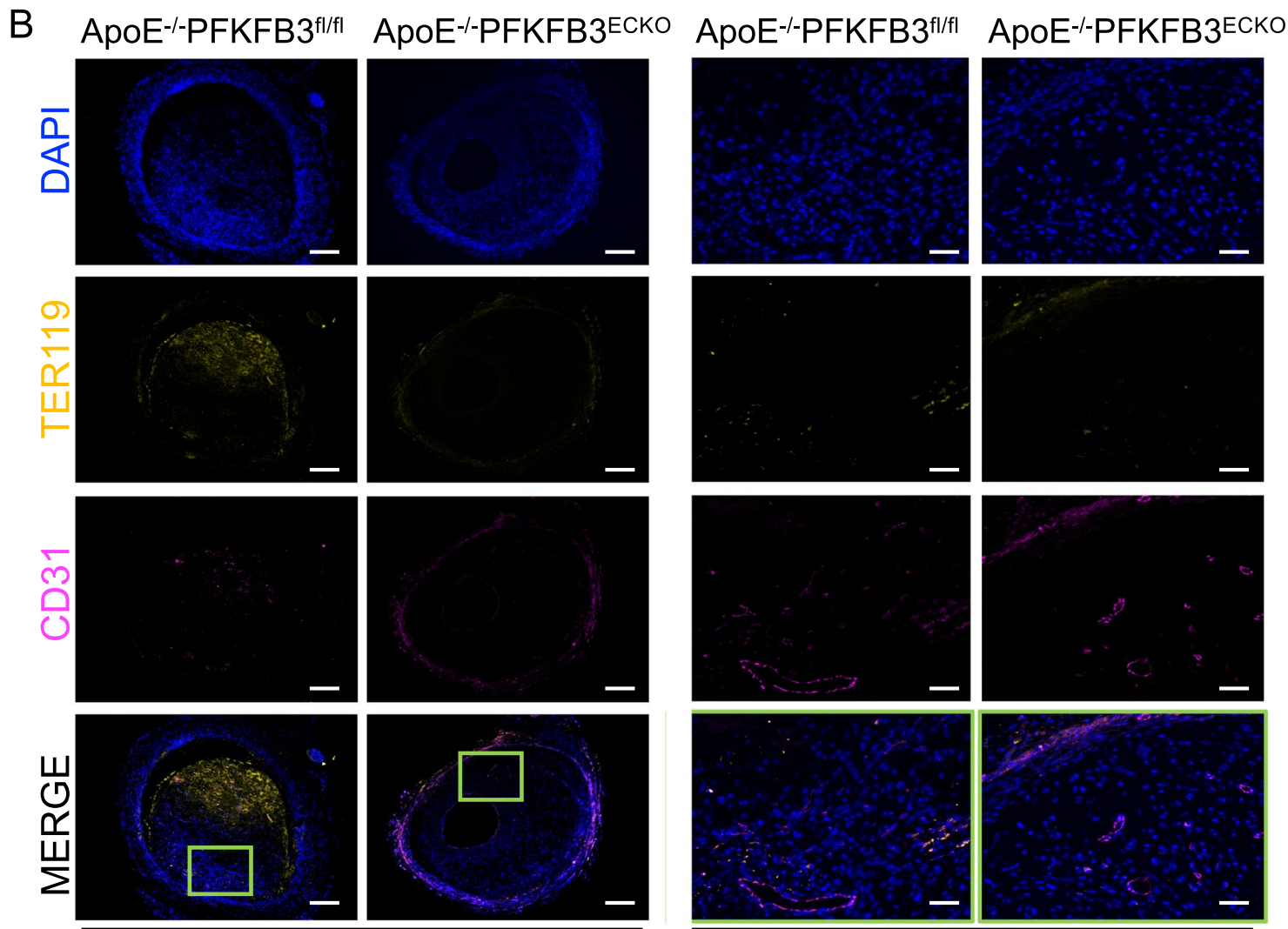

$4 \mathrm{X}$
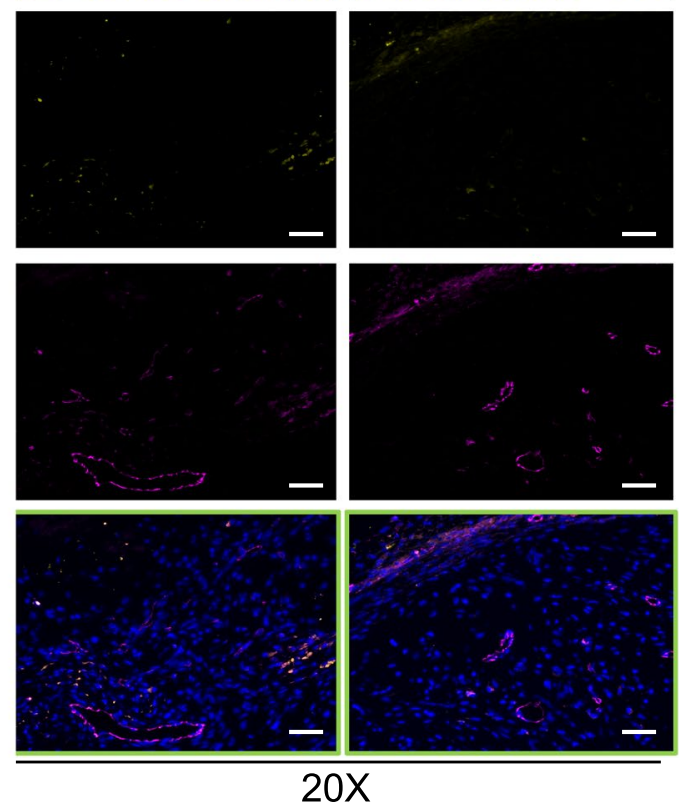

C

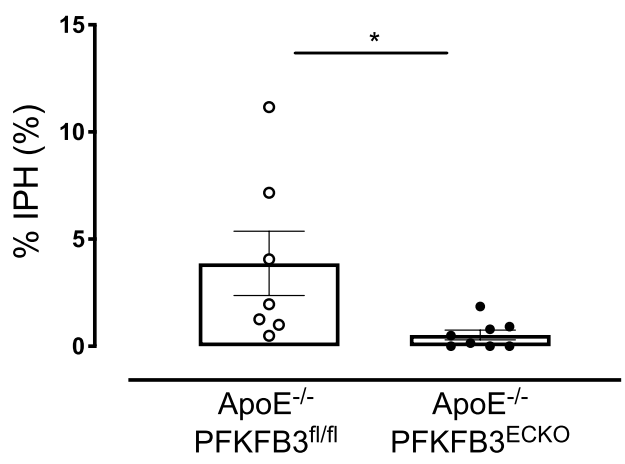

Fig. 6 PFKFB3 deficiency in endothelial cells reduces intraplaque hemorrhages (IPH) in vein graft lesions. A Representative vein graft lesions stained with anti-TER-119. TER-119 staining (red) allows detection of erythrocytes. Scale bar $=200 \mu \mathrm{m}$. B Examples of atherosclerotic lesions in vein grafts of $\mathrm{ApoE}^{-/-} \mathrm{PFKFB}^{\mathrm{fl} / \mathrm{fl}}$ and $\mathrm{ApoE}^{-/} \mathrm{PFKFB}^{\mathrm{ECKO}}$ mice stained with anti-CD31, anti-TER-119,

and DAPI. An overlay of the three stainings is also shown as well as a magnification $(20 x)$ of the boxed areas showing erythrocyte extravasation. Scale bar $=500 \mu \mathrm{m}(4 \mathrm{x})$ or $100 \mu \mathrm{m}(20 \mathrm{x})$. C Quantification of IPH. $* P=0.034$ versus ApoE ${ }^{-/-}$PFKFB3 ${ }^{\mathrm{f} / \mathrm{fl}}$. Independent samples $t$ test; $n=7\left(\mathrm{ApoE}^{-/-} \mathrm{PFKFB}^{\mathrm{fl} / \mathrm{fl}}\right)$ or $n=8\left(\mathrm{ApoE}^{-/-} \mathrm{PFKFB}^{\mathrm{ECKO}}\right)$ 
A

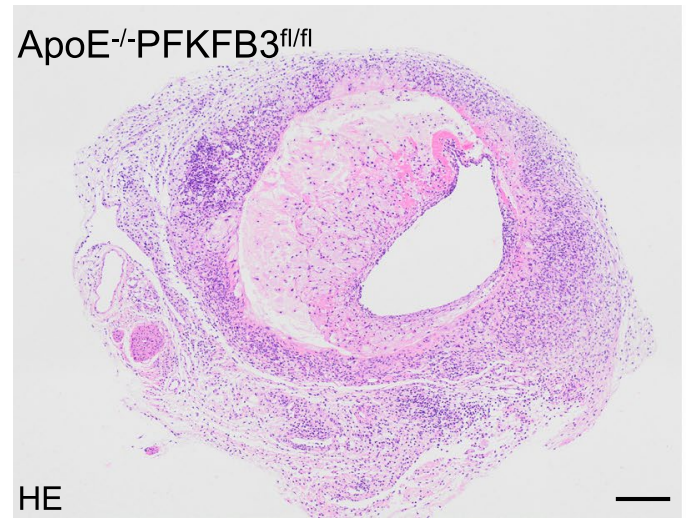

B

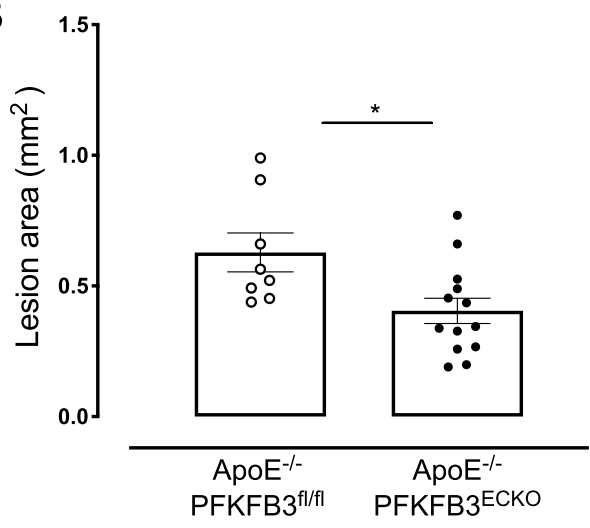

D

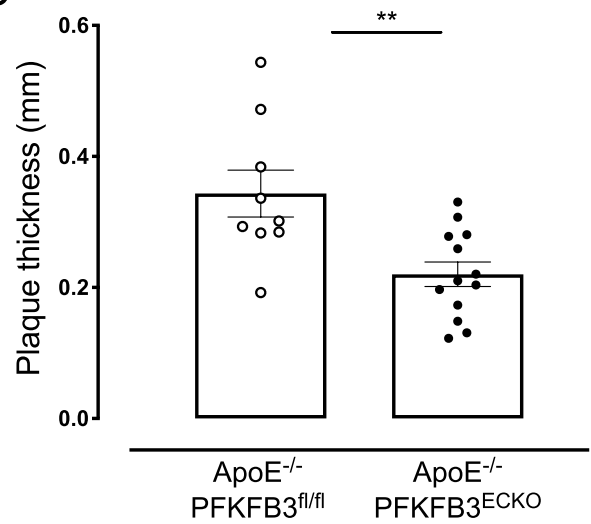

Fig. 7 PFKFB3 deficiency in endothelial cells reduces the area, percentage stenosis, thickness, and necrotic area of vein graft lesions. A Representative cross sections of hematoxylin \& eosin-stained vein grafts from $\mathrm{ApoE}^{-/-} \mathrm{PFKFB}^{\mathrm{t} / / \mathrm{fl}}$ and $\mathrm{ApoE}^{-/} \mathrm{PFKFB}^{\mathrm{ECKO}}$ mice. Scale bar $=200 \mu \mathrm{m}$. B-E Quantification of lesion area, percentage

coverage and less leakage of erythrocytes inside the graft lesion. These findings are consistent with recent in vitro and in vivo observations showing that PFKFB3 inhibition reduces VE-cadherin endocytosis and promotes normalization of the endothelial barrier by tightening EC junctions [16]. Apart from PFKFB3 inhibition, we recently reported
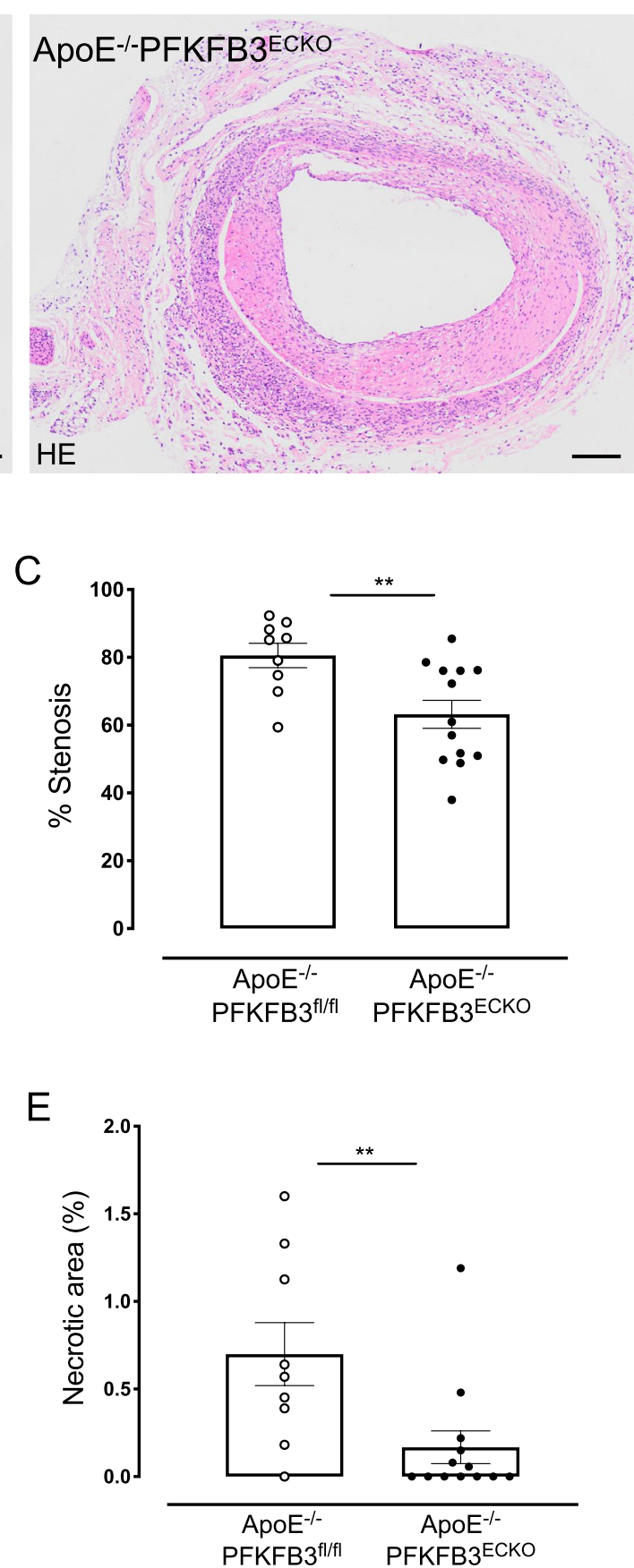

stenosis, thickness, and necrotic area of vein graft lesions. ${ }^{*} P=0.01$, $* * P=0.0095$ versus $A$ poE $^{-/}-\mathrm{PFKFB} 3^{\mathrm{f} / \mathrm{fl}}$. Independent samples $t$ test; $n=8 \quad\left(\mathrm{ApoE}^{-/-} \mathrm{PFKFB}^{\mathrm{fl} / \mathrm{fl}}\right.$, panel B), $n=9 \quad\left(\mathrm{ApoE}^{-/} \mathrm{PFKFB}^{\mathrm{fl} / \mathrm{fl}}\right.$, panel C-E), or $n=13$ (ApoE ${ }^{-/-}$PFKFB3 $^{\mathrm{ECKO}}$ )

that also atorvastatin promotes IP vessel maturation in vein grafts by preventing VE-cadherin internalization and increasing pericyte coverage [9].

We also observed a reduction in plaque size in vein grafts of $\mathrm{ApoE}^{-/} \mathrm{PFKFB}^{\mathrm{ECKO}}$ mice, which suggests that PFKFB3 may play a direct role in plaque progression. Such 

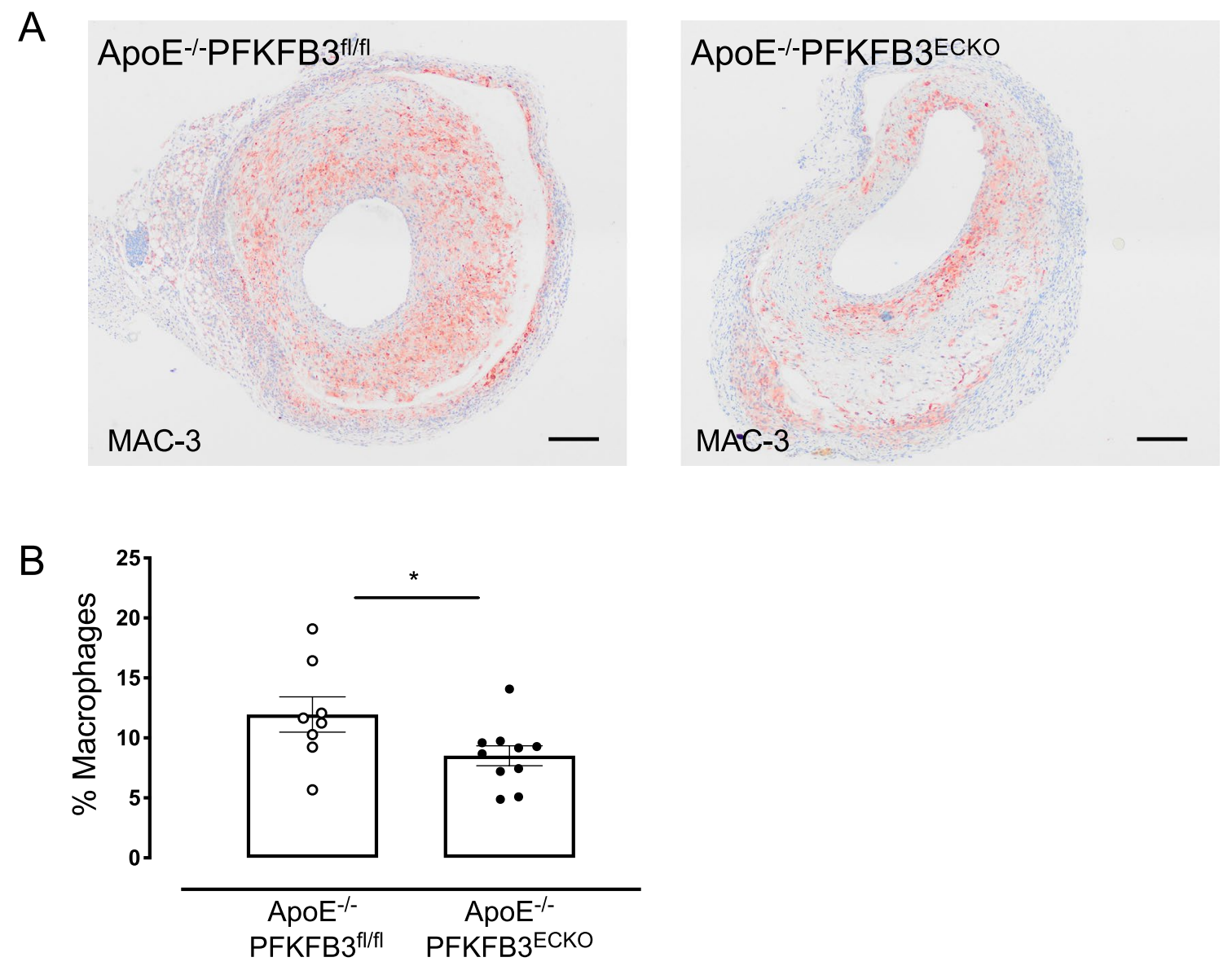

Fig. 8 PFKFB3 deficiency in endothelial cells reduces macrophage infiltration in vein graft lesions. A Immunohistochemical detection of macrophages in representative vein graft lesions of $\mathrm{ApoE}^{-/-} \mathrm{PFKFB}^{\mathrm{fl} / \mathrm{fl}}$ and $\mathrm{ApoE} \mathrm{E}^{-/-} \mathrm{PFKFB}^{\mathrm{ECKO}}$ mice using MAC-3 antibody. Scale bar $=200 \mu \mathrm{m}$. B Quantification of macrophages in

compelling possibility corresponds with data from in vitro studies showing that PFKFB3 is linked to pro-inflammatory signaling of ECs in response to blood flow shear stress. Indeed, turbulent blood flow in atheroprone regions leads to inhibition of Krüppel-like Factor 2 activity, which correlates with PFKFB3 upregulation, increased EC glycolysis, and inflammatory activation [26]. The importance of PFKFB3 in plaque progression has also been suggested by a recent study showing a positive correlation between PFKFB3 expression and an unstable plaque phenotype in both carotid and coronary plaques in humans [25]. Furthermore, administration of the PFKFB3 inhibitor PFK158 in mice led to a reduction in advanced plaques with a vulnerable phenotype and an increase in plaque stability [25]. The reduction of IP angiogenesis in $\mathrm{ApoE}^{-/-} \mathrm{PFKFB}^{\mathrm{ECKO}}$ mice, as described in this study, is also in line with previous findings in our group showing decreased IP angiogenesis following administration of the glycolysis inhibitor 3PO in a mouse model of advanced atherosclerosis [19]. In this perspective, it is vein graft lesions of $\mathrm{ApoE}^{-/-} \mathrm{PFKFB}^{\mathrm{f} / \mathrm{fl}}$ and $\mathrm{ApoE}{ }^{-/-} \mathrm{PFKFB}^{\mathrm{ECKO}}$ mice. $* P=0.047$ versus $A$ poE $^{-/-} \mathrm{PFKFB} 3^{\mathrm{fl} / \mathrm{fl}}$ mice. Independent samples $t$ test; $n=8\left(\mathrm{ApoE}^{-/} \mathrm{PFKFB}^{\mathrm{f} / / \mathrm{fl}}\right)$ or $n=10$ $\left(\mathrm{ApoE}^{-/-} \mathrm{PFKFB}^{\mathrm{ECKO}}\right.$ )

worth mentioning that $3 \mathrm{PO}$ significantly reduced initiation of plaque formation in a preventive study design.

Most interestingly, we detected a reduction in the percentage of macrophage infiltration in vein graft lesions of $\mathrm{ApoE}^{-/-} \mathrm{PFKFB}^{\mathrm{ECKO}}$ mice. This finding is in agreement with the presence of crosstalk between EC metabolism and macrophages in pathological conditions, as previously reported [27, 28]. For example, in tumor settings a metabolic competition for glucose between EC and macrophages reduces EC hyperactivation and prevents abnormal vessel leakage [29]. However, both immunohistochemical stains and RT-PCR analysis of endothelial adhesion molecules did not reveal significant differences in $\mathrm{ApoE}^{-/-}$PFKFB3 ${ }^{\mathrm{ECKO}}$ mice as compared to ApoE ${ }^{-/-}$PFKFB $3^{\mathrm{f} / \mathrm{fl}}$ mice. PFKFB3 inhibition also abolishes the inflammatory response caused by lipoprotein(a) with concomitant attenuation of transendothelial monocyte migration in atherosclerotic plaques [30]. It is therefore possible that the observed reduction in macrophage 

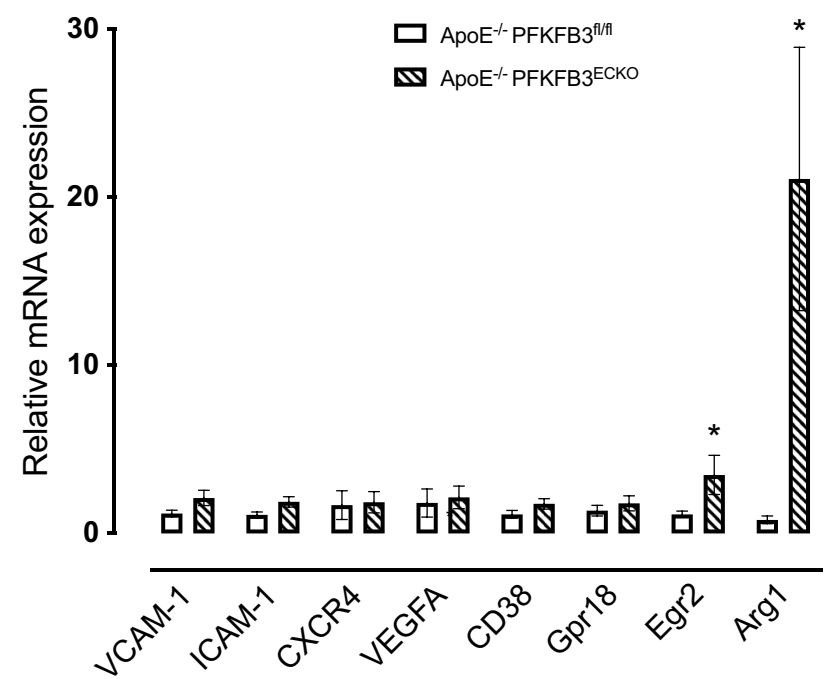

Fig. 9 Real-time RT-PCR analysis of endothelial adhesion molecules, hypoxia markers, and M1/M2 macrophage markers in vein grafts of ApoE ${ }^{-/-}$PFKFB3 $^{\text {fl/fl }}$ and ApoE ${ }^{-/-}$PFKFB ${ }^{\text {ECKO }}$ mice. Total RNA was isolated from vein grafts of $\mathrm{ApoE}^{-/-} \mathrm{PFKFB}^{\mathrm{fl} / \mathrm{fl}}$ (PFKFB3 ${ }^{\mathrm{f} / \mathrm{fl}}$ ) and ApoE $^{-/}$PFKFB3 $^{\text {ECKO }}$ (PFKFB3 ${ }^{\text {ECKO }}$ ) mice. Subsequently, mRNA expression of the endothelial adhesion molecules VCAM-1 (vascular cell adhesion molecule-1) and ICAM-1 (intercellular adhesion molecule-1), hypoxia markers CXCR4 (C-X-C chemokine receptor 4) and VEGFA (vascular endothelial growth factor A), M1 exclusive genes CD38 and G-protein coupled receptor 18 (Gpr18) as well as M2-specific markers Egr2 (Early growth response protein 2) and Arg1 (Arginase-1) was analyzed by real-time RT-PCR. $* P<0.05$ versus PFKFB $3^{\mathrm{f} / / \mathrm{fl}}$. Independent samples $t$ test; $n=9\left(\mathrm{ApoE}^{-/-} \mathrm{PFKFB}^{\mathrm{f} /}\right.$ $\left.{ }^{\mathrm{fl}}\right)$ or $n=12\left(\mathrm{ApoE}^{-/-} \mathrm{PFKFB}^{\mathrm{ECKO}}\right)$

infiltration in vivo is in part due to an improved restoration of EC junctions after PFKFB3 deletion, as mentioned above. Interestingly, vein grafts of $\mathrm{ApoE}^{-1-} \mathrm{PFKFB}^{\text {ЕСKO }}$ mice revealed an elevated $\mathrm{M} 2$ macrophage signature. In particular the canonical M2 macrophage marker Arg-1 was strongly upregulated. Changes in CD38 and Gpr18, which are exclusive M1 markers [31] could not be demonstrated. M2 macrophages resolve inflammation and are usually associated with lesion regression, which corresponds to the improved phenotype of $\mathrm{ApoE}^{-/-} \mathrm{PFKFB}^{\mathrm{ECKO}}$ vein grafts. However, it is presently unclear what drives M2 polarization in our experimental settings. We previously reported that glycolysis inhibitor $3 \mathrm{PO}$ promotes a macrophage M2 phenotype by stimulating the expression of Arg1 and the exclusive M2 marker Egr2 [19]. Given that VE-cadherin-Cre (used to delete PFKFB3 in ECs) may also show recombinase activity in hematopoietic cells [32] we cannot rule out the possibility that also macrophages are (partially) PFKFB3 deficient. Importantly, myeloid knockdown of PFKFB3 does not affect the size and composition of plaques in atherosclerotic mice [33], suggesting that endothelial PFKFB3 deficiency and not myeloid PFKFB3 deficiency remains a key condition to suppress lesion formation and to obtain an improved lesion phenotype.

Altogether, our findings indicate that endothelial PFKFB3 plays a critical role in IP angiogenesis and lesion progression, and that PFKFB3 inhibition is a promising approach to prevent plaque development and to reduce the complications of vein bypass grafting.

Supplementary Information The online version contains supplementary material available at https://doi.org/10.1007/s10456-021-09816-3.

Acknowledgements The authors would like to thank Dr. Laurence Roosens, Anne-Elise Van Hoydonck, Hermine Fret, Rita Van den Bossche, Mandy Vermont, and Melissa Van Praet for technical help. VE-cadherin (PAC)-Cre ${ }^{\text {ERT2 }}$ mice were a kind gift from Prof. Peter Carmeliet (KULeuven, Belgium). The authors are grateful to Dr. Bronwen Martin for critical reading of the manuscript.

Author contributions PP, MRDV, PQ, and WM designed the research. PP and MRDV performed the study. All authors contributed to the analysis and interpretation of data. All authors also helped drafting the manuscript and approved the final version of the manuscript.

Funding This work was supported by the University of Antwerp [DOCPRO-BOF], iBOF [Grant Number iBOF-21-053] and the Horizon 2020 program of the European Union - Marie Sklodowska Curie actions - ITN - MOGLYNET [Grant Number 675527].

Data availability The authors declare that all supporting data are available within the article (and its data supplement).

\section{Declarations}

Conflict of interest The authors have stated explicitly that there are no conflict of interest in connection with this article.

Ethical approval All animal procedures were conducted according to the guidelines from Directive 2010/63/EU of the European Parliament on the protection of animals used for scientific purposes. Experiments were approved by the ethics committee of the University of Antwerp (reference number 2017-96).

Open Access This article is licensed under a Creative Commons Attribution 4.0 International License, which permits use, sharing, adaptation, distribution and reproduction in any medium or format, as long as you give appropriate credit to the original author(s) and the source, provide a link to the Creative Commons licence, and indicate if changes were made. The images or other third party material in this article are included in the article's Creative Commons licence, unless indicated otherwise in a credit line to the material. If material is not included in the article's Creative Commons licence and your intended use is not permitted by statutory regulation or exceeds the permitted use, you will need to obtain permission directly from the copyright holder. To view a copy of this licence, visit http://creativecommons.org/licenses/by/4.0/.

\section{References}

1. Virmani R, Atkinson JB, Forman MB (1988) Aortocoronary saphenous vein bypass grafts. Cardiovasc Clin 18(2):41-62 
2. de Vries MR, Quax PHA (2018) Inflammation in Vein Graft Disease. Front Cardiovasc Med 5:3. doi:https://doi.org/10.3389/fcvm. 2018.00003

3. de Vries MR, Simons KH, Jukema JW, Braun J, Quax PH (2016) Vein graft failure: from pathophysiology to clinical outcomes. Nat Rev Cardiol 13(8):451-470. doi:https://doi.org/10.1038/nrcardio. 2016.76

4. Yahagi K, Kolodgie FD, Otsuka F, Finn AV, Davis HR, Joner M, Virmani R (2016) Pathophysiology of native coronary, vein graft, and in-stent atherosclerosis. Nat Rev Cardiol 13(2):79-98. doi:https://doi.org/10.1038/nrcardio.2015.164

5. de Vries MR, Niessen HW, Lowik CW, Hamming JF, Jukema JW, Quax PH (2012) Plaque rupture complications in murine atherosclerotic vein grafts can be prevented by TIMP-1 overexpression. PLoS ONE 7(10):e47134. https://doi.org/10.1371/journal.pone. 0047134

6. Janiec M, Nazari Shafti TZ, Dimberg A, Lagerqvist B, Lindblom RPF (2018) Graft failure and recurrence of symptoms after coronary artery bypass grafting. Scand Cardiovasc J 52(3):113-119. doi:https://doi.org/10.1080/14017431.2018.1442930

7. de Vries MR, Parma L, Peters HAB, Schepers A, Hamming JF, Jukema JW, Goumans M, Guo L, Finn AV, Virmani R, Ozaki CK, Quax PHA (2019) Blockade of vascular endothelial growth factor receptor 2 inhibits intraplaque haemorrhage by normalization of plaque neovessels. J Intern Med 285(1):59-74. doi:https://doi.org/ 10.1111/joim.12821

8. Aarup A, Pedersen TX, Junker N, Christoffersen C, Bartels ED, Madsen M, Nielsen CH, Nielsen LB (2016) Hypoxia-Inducible Factor-1alpha Expression in Macrophages Promotes Development of Atherosclerosis. Arterioscler Thromb Vasc Biol 36(9):17821790. doi:https://doi.org/10.1161/ATVBAHA.116.307830

9. Baganha F, de Jong RCM, Peters EA, Voorham W, Jukema JW, Delibegovic M, de Vries MR, Quax PHA (2021) Atorvastatin pleiotropically decreases intraplaque angiogenesis and intraplaque haemorrhage by inhibiting ANGPT2 release and VE-Cadherin internalization. Angiogenesis. doi:https://doi.org/10.1007/ s10456-021-09767-9

10. Parma L, Baganha F, Quax PHA, de Vries MR (2017) Plaque angiogenesis and intraplaque hemorrhage in atherosclerosis. Eur J Pharmacol 816:107-115. doi:https://doi.org/10.1016/j.ejphar. 2017.04.028

11. de Vries MR, Quax PH (2016) Plaque angiogenesis and its relation to inflammation and atherosclerotic plaque destabilization. Curr Opin Lipidol 27(5):499-506. doi:https://doi.org/10.1097/ MOL.0000000000000339

12. Carmeliet $P$ (2003) Angiogenesis in health and disease. Nat Med 9(6):653-660. doi:https://doi.org/10.1038/nm0603-653

13. Cantelmo AR, Brajic A, Carmeliet P (2015) Endothelial Metabolism Driving Angiogenesis: Emerging Concepts and Principles. Cancer J 21(4):244-249. doi:https://doi.org/10.1097/PPO.00000 00000000133

14. Eelen G, de Zeeuw P, Treps L, Harjes U, Wong BW, Carmeliet P (2018) Endothelial Cell Metabolism. Physiol Rev 98(1):3-58. doi:https://doi.org/10.1152/physrev.00001.2017

15. Tawakol A, Singh P, Mojena M, Pimentel-Santillana M, Emami H, MacNabb M, Rudd JH, Narula J, Enriquez JA, Traves PG, Fernandez-Velasco M, Bartrons R, Martin-Sanz P, Fayad ZA, Tejedor A, Bosca L (2015) HIF-1alpha and PFKFB3 Mediate a Tight Relationship Between Proinflammatory Activation and Anerobic Metabolism in Atherosclerotic Macrophages. Arterioscler Thromb Vasc Biol 35(6):1463-1471. doi:https://doi.org/10. 1161/ATVBAHA.115.305551

16. Cantelmo AR, Conradi LC, Brajic A, Goveia J, Kalucka J, Pircher A, Chaturvedi P, Hol J, Thienpont B, Teuwen LA, Schoors S, Boeckx B, Vriens J, Kuchnio A, Veys K, Cruys B, Finotto L, Treps L, Stav-Noraas TE, Bifari F, Stapor P, Decimo I, Kampen
K, De Bock K, Haraldsen G, Schoonjans L, Rabelink T, Eelen G, Ghesquiere B, Rehman J, Lambrechts D, Malik AB, Dewerchin M, Carmeliet P (2016) Inhibition of the Glycolytic Activator PFKFB3 in Endothelium Induces Tumor Vessel Normalization, Impairs Metastasis, and Improves Chemotherapy. Cancer Cell 30(6):968-985. doi:https://doi.org/10.1016/j.ccell.2016.10.006

17. Schoors S, De Bock K, Cantelmo AR, Georgiadou M, Ghesquiere B, Cauwenberghs S, Kuchnio A, Wong BW, Quaegebeur A, Goveia J, Bifari F, Wang X, Blanco R, Tembuyser B, Cornelissen I, Bouche A, Vinckier S, Diaz-Moralli S, Gerhardt H, Telang S, Cascante M, Chesney J, Dewerchin M, Carmeliet P (2014) Partial and transient reduction of glycolysis by PFKFB3 blockade reduces pathological angiogenesis. Cell Metab 19(1):37-48. doi:https:// doi.org/10.1016/j.cmet.2013.11.008

18. De Bock K, Georgiadou M, Schoors S, Kuchnio A, Wong BW, Cantelmo AR, Quaegebeur A, Ghesquiere B, Cauwenberghs S, Eelen G, Phng LK, Betz I, Tembuyser B, Brepoels K, Welti J, Geudens I, Segura I, Cruys B, Bifari F, Decimo I, Blanco R, Wyns S, Vangindertael J, Rocha S, Collins RT, Munck S, Daelemans D, Imamura H, Devlieger R, Rider M, Van Veldhoven PP, Schuit F, Bartrons R, Hofkens J, Fraisl P, Telang S, Deberardinis RJ, Schoonjans L, Vinckier S, Chesney J, Gerhardt H, Dewerchin M, Carmeliet P (2013) Role of PFKFB3-driven glycolysis in vessel sprouting. Cell 154(3):651-663. doi:https://doi.org/10.1016/j.cell. 2013.06.037

19. Perrotta P, Van der Veken B, Van Der Veken P, Pintelon I, Roosens L, Adriaenssens E, Timmerman V, Guns PJ, De Meyer GRY, Martinet W (2020) Partial inhibition of glycolysis reduces atherogenesis independent of intraplaque neovascularization in mice. Arterioscler Thromb Vasc Biol 40(5):1168-1181. https://doi.org/ 10.1161/ATVBAHA.119.313692

20. Landskroner-Eiger S, Qiu C, Perrotta P, Siragusa M, Lee MY, Ulrich V, Luciano AK, Zhuang ZW, Corti F, Simons M, Montgomery RL, Wu D, Yu J, Sessa WC (2015) Endothelial miR-17 approximately 92 cluster negatively regulates arteriogenesis via miRNA-19 repression of WNT signaling. Proc Natl Acad Sci U S A 112(41):12812-12817. doi:https://doi.org/10.1073/pnas.15070 94112

21. Nowak-Sliwinska P, Alitalo K, Allen E, Anisimov A, Aplin AC, Auerbach R, Augustin HG, Bates DO, van Beijnum JR, Bender RHF, Bergers G, Bikfalvi A, Bischoff J, Bock BC, Brooks PC, Bussolino F, Cakir B, Carmeliet P, Castranova D, Cimpean AM, Cleaver O, Coukos G, Davis GE, De Palma M, Dimberg A, Dings RPM, Djonov V, Dudley AC, Dufton NP, Fendt SM, Ferrara N, Fruttiger M, Fukumura D, Ghesquiere B, Gong Y, Griffin RJ, Harris AL, Hughes CCW, Hultgren NW, Iruela-Arispe ML, Irving M, Jain RK, Kalluri R, Kalucka J, Kerbel RS, Kitajewski J, Klaassen I, Kleinmann HK, Koolwijk P, Kuczynski E, Kwak BR, Marien K, Melero-Martin JM, Munn LL, Nicosia RF, Noel A, Nurro J, Olsson AK, Petrova TV, Pietras K, Pili R, Pollard JW, Post MJ, Quax PHA, Rabinovich GA, Raica M, Randi AM, Ribatti D, Ruegg C, Schlingemann RO, Schulte-Merker S, Smith LEH, Song JW, Stacker SA, Stalin J, Stratman AN, Van de VM, van Hinsbergh, Vermeulen VWM, Waltenberger PB, Weinstein J, Xin BM, Yetkin-Arik H, Yla-Herttuala B, Yoder S, Griffioen MC AW (2018) Consensus guidelines for the use and interpretation of angiogenesis assays. Angiogenesis 21(3):425-532. doi:https://doi. org/10.1007/s10456-018-9613-x

22. Corti F, Wang Y, Rhodes JM, Atri D, Archer-Hartmann S, Zhang J, Zhuang ZW, Chen D, Wang T, Wang Z, Azadi P, Simons M (2019) N-terminal syndecan-2 domain selectively enhances 6-O heparan sulfate chains sulfation and promotes VEGFA165dependent neovascularization. Nat Commun 10(1):1562. doi:https://doi.org/10.1038/s41467-019-09605-z

23. Wang Y, Nakayama M, Pitulescu ME, Schmidt TS, Bochenek ML, Sakakibara A, Adams S, Davy A, Deutsch U, Luthi U, Barberis A, 
Benjamin LE, Makinen T, Nobes CD, Adams RH (2010) EphrinB2 controls VEGF-induced angiogenesis and lymphangiogenesis. Nature 465(7297):483-486. doi:https://doi.org/10.1038/natur e09002

24. Parma L, Peters HAB, Baganha F, Sluimer JC, de Vries MR, Quax PHA (2020) Prolonged hyperoxygenation treatment improves vein graft patency and decreases macrophage content in atherosclerotic lesions in ApoE3*Leiden mice. Cells 9(2):336. https://doi.org/10. 3390/cells9020336

25. Poels K, Schnitzler JG, Waissi F, Levels JHM, Stroes ESG, Daemen M, Lutgens E, Pennekamp AM, De Kleijn DPV, Seijkens TTP, Kroon J (2020) Inhibition of PFKFB3 Hampers the Progression of Atherosclerosis and Promotes Plaque Stability. Front Cell Dev Biol 8:581641. doi:https://doi.org/10.3389/fcell.2020.581641

26. Doddaballapur A, Michalik KM, Manavski Y, Lucas T, Houtkooper RH, You X, Chen W, Zeiher AM, Potente M, Dimmeler S, Boon RA (2015) Laminar shear stress inhibits endothelial cell metabolism via KLF2-mediated repression of PFKFB3. Arterioscler Thromb Vasc Biol 35(1):137-145. doi:https://doi.org/10. 1161/ATVBAHA.114.304277

27. Baer C, Squadrito ML, Iruela-Arispe ML, De Palma M (2013) Reciprocal interactions between endothelial cells and macrophages in angiogenic vascular niches. Exp Cell Res 319(11):1626-1634. doi:https://doi.org/10.1016/j.yexcr.2013. 03.026

28. Kalucka J, Bierhansl L, Wielockx B, Carmeliet P, Eelen G (2017) Interaction of endothelial cells with macrophages-linking molecular and metabolic signaling. Pflugers Arch 469(3-4):473-483. doi:https://doi.org/10.1007/s00424-017-1946-6

29. Wenes M, Shang M, Di Matteo M, Goveia J, Martin-Perez R, Serneels J, Prenen H, Ghesquiere B, Carmeliet P, Mazzone M (2016)
Macrophage Metabolism Controls Tumor Blood Vessel Morphogenesis and Metastasis. Cell Metab 24(5):701-715. doi:https:// doi.org/10.1016/j.cmet.2016.09.008

30. Schnitzler JG, Hoogeveen RM, Ali L, Prange KHM, Waissi F, van Weeghel M, Bachmann JC, Versloot M, Borrelli MJ, Yeang C, De Kleijn DPV, Houtkooper RH, Koschinsky ML, de Winther MPJ, Groen AK, Witztum JL, Tsimikas S, Stroes ESG, Kroon J (2020) Atherogenic Lipoprotein(a) Increases Vascular Glycolysis, Thereby Facilitating Inflammation and Leukocyte Extravasation. Circ Res 126(10):1346-1359. doi:https://doi.org/10.1161/CIRCR ESAHA.119.316206

31. Jablonski KA, Amici SA, Webb LM, Ruiz-Rosado Jde D, Popovich PG, Partida-Sanchez S, Guerau-de-Arellano M (2015) Novel markers to delineate murine M1 and M2 macrophages. PLoS ONE 10(12):e0145342. https://doi.org/10.1371/journal.pone.0145342

32. Payne S, De Val S, Neal A (2018) Endothelial-Specific Cre Mouse Models. Arterioscler Thromb Vasc Biol 38(11):2550-2561. doi:https://doi.org/10.1161/ATVBAHA.118.309669

33. De Bruijn J, van Kuijk K, Bijnen M, Gijbels M, Wouters K, Carmeliet P, Sluimer J (2019) Partial inhibition of the key glycolytic enzyme Pfkfb3 in myeloid cells impacts whole-body immune cell and liver metabolism, but not atherogenesis. Atherosclerosis 287:e19-e20. https://doi.org/10.1016/j.atherosclerosis.2019.06. 055

Publisher's Note Springer Nature remains neutral with regard to jurisdictional claims in published maps and institutional affiliations. 